\title{
Heterogeneous in vitro effects of doxorubicin on gene expression in primary human liposarcoma cultures Adrien Daigeler*1, Ludger Klein-Hitpass ${ }^{2}$, Michael Ansgar Chromik², Oliver Müller ${ }^{4}$, Jörg Hauser ${ }^{1}$, Heinz-Herbert Homann ${ }^{1}$, Hans-Ulrich Steinau ${ }^{1}$ and Marcus Lehnhardt ${ }^{1}$
}

\author{
Address: ${ }^{1}$ Department of Plastic Surgery, Burn Center, Hand surgery, Sarcoma Reference Center, BG-University Hospital Bergmannsheil, Ruhr \\ University Bochum, Bürkle-de-la-Camp-Platz 1, 44789 Bochum, Germany, ${ }^{2}$ Institute of Cell Biology (Tumor Research), IFZ, University of Essen, \\ Virchowstr. 173, 45122 Essen, Germany, ${ }^{3}$ Department of Surgery, St. Josef Hospital, Ruhr-University, Bochum, Germany and ${ }^{4}$ Tumor Genetics \\ Group, Max-Planck-Institut für molekulare Physiologie, Otto Hahnstr. 11, 44227 Dortmund, Germany \\ Email: Daigeler Adrien* - adrien.daigeler@rub.de; Klein-Hitpass Ludger - ludger.klein-hitpass@uk-essen.de; \\ Chromik Ansgar Michael - ansgar_chromik@gmx.de; Müller Oliver - oliver.mueller@mpi-dortmund.mpg.de; \\ Hauser Jörg - joerg.hauser@rub.de; Homann Heinz-Herbert - heinz.homann@rub.de; Steinau Hans-Ulrich - hans- \\ ulrich.steinau@bergmannsheil.de; Lehnhardt Marcus - marcus.lehnhardt@rub.de \\ * Corresponding author
}

Published: 29 October 2008

BMC Cancer 2008, 8:313 doi:10.1 186/|47|-2407-8-3/3

This article is available from: http://www.biomedcentral.com/I47I-2407/8/3।3

(C) 2008 Adrien et al; licensee BioMed Central Ltd.

This is an Open Access article distributed under the terms of the Creative Commons Attribution License (http://creativecommons.org/licenses/by/2.0), which permits unrestricted use, distribution, and reproduction in any medium, provided the original work is properly cited.
Received: 17 December 2007

Accepted: 29 October 2008

\begin{abstract}
Background: Doxorubicin is considered one of the most potent established chemotherapeutics in the treatment of liposarcoma; however, the response rates usually below $30 \%$, are still disappointing. This study was performed to identify gene expression changes in liposarcoma after doxorubicin treatment.
\end{abstract}

Methods: Cells of 19 primary human liposarcoma were harvested intraoperatively and brought into cell culture. Cells were incubated with doxorubicin for $24 \mathrm{~h}$, RNA was isolated and differential gene expression was analysed by the microarray technique.

Results: A variety of genes involved in apoptosis were up and down regulated in different samples revealing a heterogeneous expression pattern of the 19 primary tumor cell cultures in response to doxorubicin treatment. However, more than $50 \%$ of the samples showed up-regulation of proapoptotic genes such as TRAIL Receptor2, CDKNIA, GADD45A, FAS, CD40, PAWR, NFKBIA, IER3, PSENI, RIPK2, and CD44. The anti-apoptotic genes TNFAIP3, PEAI5, BCI2AI, NGFB, and BIRC3 were also up-regulated. The pro-apoptotic CDI4, TIAI, and ITGB2 were down-regulated in more than $50 \%$ of the tumor cultures after treatment with doxorubicin, as was the antiapoptotic $Y W H A H$.

Conclusion: Despite a correlation of the number of differentially regulated genes to the tumor grading and to a lesser extent histological subtype, the expression patterns varied strongly; however, especially among high grade tumors the responses of selected apoptosis genes were similar. The predescribed low clinical response rates of low grade liposarcoma to doxorubicin correspond to our results with only little changes on gene expression level and also divergent findings concerning the up- and down-regulation of single genes in the different sarcoma samples. 


\section{Background}

Together with malignant fibrous histiocytoma (not otherwise specified sarcoma, NOS), liposarcoma represents the most common entity of soft tissue sarcomas and accounts for approximately $20 \%$ of sarcomas in adults [1-3]. Although surgery and radiation therapy could achieve good results concerning local control, distant metastatic disease remains a therapeutic dilemma limiting survival $[4,5]$. With a maximum response rate of approximately $20 \%$ the effects of cytostatics on liposarcoma are still disappointing [6-8]. The most favoured chemotherapeutics for treatment of advanced soft tissue sarcoma, including liposarcoma, are ifosfamide and doxorubicin, but the data for ifosfamide differ with respect to improvement of local control and survival [9-11]. Although meta-analysis of 14 randomised trials found that doxorubicin treatment was associated with a $10 \%$ improvement of recurrence free survival, the overall survival could not be improved [1214]. In carcinomas, multiple mechanisms of drug resistance on the molecular level have been characterized $[15,16]$ including over-expression of $p 53$ [17-20], MDR1 (multidrug resistance gene 1) [20-22], MRP1 (multidrug resistance-associated protein), the induction of DNA repair [20] and many others involving tumor suppressor genes, oncogenes, cell cycle regulators, transcription factors, growth factor receptors, and cell death regulators. Only little is known about the molecular basis of drug resistance in soft tissue sarcomas and studies on the effect of cytostatics on gene expression, especially in liposarcomas [23-27], are rare. Comprehensive knowledge of the differential expression patterns induced by cytotoxic drugs may be useful for examining the molecular basis of drug effects and also drug resistance. Because of the limited comparability of established purchasable sarcoma cell lines to in vivo tumors, we primarily harvested liposarcoma cells from resection specimens, incubated the cultured cells with doxorubicin and evaluated the changes in gene expression with a focus on genes related to apoptotic pathways. To the authors' knowledge, to date there are no studies that examined the effects of doxorubicin on primary human liposarcoma on a molecular basis.

\section{Methods}

Primary human liposarcoma tumor samples of at least 1 $\mathrm{cm}^{3}$ were harvested intraoperatively from patients undergoing resection of an already diagnosed liposarcoma and immediately processed under sterile conditions. Seven atypical lipomas (low grade sarcomas), four dedifferentiated, four pleomorphic, three myxoid/round cell, and one myxoid liposarcoma were included. The grading of the tumors ranged from GI to GIII (GI: 4, GII: 8, GIII: 7). The probes were derived from primary tumors in 12, from recurrent tumors in six, and from metastasis in one case. Nineteen primary human liposarcoma cultures were isolated by dissecting the tumor and digesting the minced samples enzymatically with $10 \mathrm{ml}$ each of collagenase and dispase $(10 \mathrm{mg} / \mathrm{ml})$. The single cell suspension was depleted of red blood cells and cellular debris by centrifugation through a Ficoll-Hypaque density gradient. Liposarcoma cells were diluted and cultured during the whole experiment with Leibovitz's L-15 medium, supplemented with $2.0 \mathrm{mM}$ glutamine and $10 \%$ fetal bovine serum in a humidified atmosphere in free air exchange with atmospheric air. Cells were seeded at a density of $2 \times 10^{6}$ in 25 $\mathrm{cm}^{2}$ flasks; $24 \mathrm{~h}$ later, after having grown to a subconfluent layer, cell cultures were incubated with doxorubicin $(0.5$ $\mu \mathrm{g} / \mathrm{ml}$ ) for $24 \mathrm{~h}$ and equal volume of PBS as control [2830].

\section{Oligonucleotide microarray analysis}

For microarray analyses we used the Affymetrix Gene Chip platform employing a standard protocol for sample preparation and microarray hybridization that has been described in detail previously [26,31]. Briefly, total RNA was converted into double-stranded cDNA using an oligodeoxythymidine primer containing the T7 RNA polymerase binding site (5'-GCATTAGCGGCCGCGAAATTAATACGACTCACTATAGGGAGA - $\left.(\mathrm{dT})_{21} \mathrm{~V}-3^{\prime}\right)$ (MWG Biotech, Ebersberg, Germany) for first strand synthesis. After generation of double-stranded cDNA from the firststrand cDNA, biotinylated cRNA was synthesized by in vitro transcription using the BioArray High Yield RNA Transcript Labeling Kit (Enzo Diagnostics, New York, USA). Labeled cRNA was purified on RNeasy columns (Qiagen, Hilden, Germany) and fragmented and hybridized to HG-U133A microarrays (Affymetrix, Santa Clara, USA). The arrays were washed and stained according to the manufacturer's recommendation and finally scanned in a GeneArray scanner 2500 (Agilent, Santa Clara, USA).

Array images were processed to determine signals and detection calls (Present, Absent, Marginal) for each probeset using the Affymetrix Microarray Suite 5.0 software (MAS 5.0; statistical algorithm). The clustering was performed unsupervised. Pairwise comparisons of treated versus control samples were carried out with MAS 5.0, which calculates the significance (change p-value) of each change in gene expression based on a Wilcoxon ranking test. To limit the number of false positives, we restricted further target identification to those probesets, which received at least one present detection call in the treated/ control pair. Each single microarray analysis was derived from one cell culture. The treated cells were compared to the control. Probesets exhibiting a signal $\log 2$ ratio $>1.0$ and a change $\mathrm{p}$-value $<0.004$ or a signal $\log 2$ ratio $<-1.0$ and a change p-value $>0.996$ (corresponding to 2-fold up- or down-regulation) were identified by filtering using the Affymetrix Data Mining Tool 3.0 (Table 1). Additionally unsupervised clustering was performed between the 19 control tumor samples. 
Table I: Summarized patients' data

\begin{tabular}{|c|c|c|c|c|c|c|c|c|c|c|}
\hline Patient & Gender & $\begin{array}{l}\text { Age at } \\
\text { operation }\end{array}$ & Site & Size in $\mathrm{cm}$ & Histological subtype & $\begin{array}{l}\text { Responder } \\
\text { type }\end{array}$ & Grading & $\begin{array}{l}\text { Specimen } \\
\text { character }\end{array}$ & $\begin{array}{l}\text { Previous } \\
\text { radiation }\end{array}$ & $\begin{array}{l}\text { Previous } \\
\text { chemotherapy }\end{array}$ \\
\hline 1 & female & 69 years & lower arm & $4.5 \times 3.5 \times 2.2$ & $\begin{array}{l}\text { atypical lipoma with } \\
\text { partly dedifferentiated } \\
\text { areas }\end{array}$ & low & G2 & local recurrence & no & no \\
\hline 2 & female & 74 years & Thigh & $14.5 \times 7.5 \times 9$ & $\begin{array}{l}\text { myxoid/roundcell } \\
\text { liposarcoma }\end{array}$ & high & G3 & primary tumor & no & no \\
\hline 3 & female & 70 years & upper arm & $3 \times 5 \times 6$ & atypical lipoma & low & GI & primary tumor & no & no \\
\hline 4 & male & 74 years & Thigh & $16.5 \times 9 \times 7$ & $\begin{array}{l}\text { dedifferentiated } \\
\text { liposarcoma }\end{array}$ & medium & G2 & primary tumor & no & no \\
\hline 5 & male & 38 years & Knee & $8.3 \times 4 \times 7$ & myxoid liposarcoma & high & G3 & primary tumor & yes & no \\
\hline 6 & female & 58 years & $\begin{array}{l}\text { pelvis retro- } \\
\text { peritoneal }\end{array}$ & $4 \times 7 \times 9$ & $\begin{array}{l}\text { myxoid/roundcell } \\
\text { liposarcoma }\end{array}$ & high & G3 & metastasis & no & no \\
\hline 7 & male & 37 years & Thigh & $7 \times 14 \times 9$ & $\begin{array}{l}\text { myxoid/roundcell } \\
\text { liposarcoma }\end{array}$ & medium & G2 & primary tumor & no & yes \\
\hline 8 & female & 85 years & lower arm & $11 \times 8 \times 4$ & $\begin{array}{l}\text { pleomorphic } \\
\text { liposarcoma }\end{array}$ & high & G3 & primary tumor & no & no \\
\hline 9 & male & 53 years & Thigh & $10 \times 3 \times 5$ & atypical liposarcoma & low & G2 & local recurrence & yes & no \\
\hline 10 & male & 76 years & Thigh & $3.5 \times 3 \times 3$ & $\begin{array}{l}\text { dedifferentiated } \\
\text { liposarcoma }\end{array}$ & high & G3 & local recurrence & yes & no \\
\hline II & female & 57 years & Thorax & $4.9 \times 4 \times 3$ & $\begin{array}{l}\text { pleomorphic } \\
\text { liposarcoma }\end{array}$ & high & G3 & local recurrence & no & no \\
\hline 12 & female & 76 years & Thigh & $38.5 \times 17.5 \times 6$ & atypical lipoma & low & GI & primary tumor & no & no \\
\hline 13 & female & 74 years & Thigh & $7 \times 6 \times 4$ & $\begin{array}{l}\text { dedifferentiated } \\
\text { liposarcoma }\end{array}$ & medium & G2 & primary tumor & no & no \\
\hline 14 & female & 70 years & Thorax & $1.9 \times 1.3 \times 1$ & $\begin{array}{l}\text { pleomorphic } \\
\text { liposarcoma }\end{array}$ & medium & G2 & residual tumor & no & no \\
\hline 15 & male & 70 years & Thigh & $9 \times 3 \times 6$ & atypical lipoma & medium & GI & primary tumor & no & no \\
\hline 16 & male & 60 years & Thigh & $7.5 \times 6 \times 5.5$ & $\begin{array}{l}\text { pleomorphic } \\
\text { liposarcoma }\end{array}$ & high & G3 & primary tumor & no & no \\
\hline 17 & female & 78 years & Thigh & $13 \times 10 \times 6$ & $\begin{array}{l}\text { atypical lipoma with } \\
\text { partly dedifferentiated } \\
\text { areas }\end{array}$ & high & G2 & local recurrence & yes & no \\
\hline 18 & female & 67 years & Thigh & $35 \times 15 \times 12$ & atypical lipoma & low & GI & primary tumor & no & no \\
\hline 19 & male & 60 years & upper arm & $9,9 \times 7 \times 7$ & $\begin{array}{l}\text { dedifferentiated } \\
\text { liposarcoma }\end{array}$ & medium & G2 & local recurrence & yes & no \\
\hline
\end{tabular}


Genes associated with apoptotic pathways were selected based on Gene Ontology (GO)-analysis [32].

Expression changes were correlated to the grading and the histological sub-entity of the tumors. Only tumor samples were included in the final analysis whose gross sections were diagnosed as liposarcomas by an experienced soft tissue pathologist.

According to the number of differentially expressed genes after incubation with doxorubicin, liposarcomas were categorized into high $(\mathrm{n}>2000)$, intermediate $(100<\mathrm{n}<$ $1000)$ and low responders $(n<100)$. The results were uploaded to NCBI GEO, number GSE12972 http:// www.ncbi.nlm.n

ih.gov/geo/query/acc.cgi?acc=GSE12972.

\section{Real-time PCR for microarray data validation}

Microarray data validation was performed for selected gene products with relevant up-regulation in more than ten out of the 19 liposarcoma probes (CD40, CDKN1A, FAS, GADD45A, NFKBIA, PAWR, TNFAIP3, and TNFRSF10B) or relevant down-regulation in at least ten probes (YWHaH, PPP3CA, and ITGB2). CD14 and TIA were not tested because no high quality PCR assays were purchasable.

Total RNA $(2 \mu \mathrm{g})$ was reverse transcribed using the High Capacity cDNA Archive Kit (Applied Biosystems). Realtime PCR was done with a 7900HT SDS system (Applied Biosystems) in $20 \mu \mathrm{l}$ reaction volume containing $1 \times$ Master Mix, $1 \mu \mathrm{l}$ assay and cDNA equivalent to $2 \mathrm{ng}$ total RNA. All reagents and realtime PCR assays ( $\mathrm{m} 1$ type only; CD40_Hs00386848_1, CDKN1A_Hs00355782_m1， FAS_Hs00236330_m1, GADD45A_Hs00169255_m1， ITGB2_Hs00164957_m1, NFKBIA_Hs00153283_m1， PAWR_Hs00169332_m1, PPP3CA_Hs00174223_m1， TNFAIP3_Hs00234713_m1, TNFRSF10B_Hs00366272_m1，YWHaH_Hs00607046_m1) used were purchased from Applied Biosystems. Reactions were performed in duplicates and analysed by the deltadeltaCT method. Human GAPD was used for normalization. Pearson correlation of the microarray and the rtPCR data was calculated using SPSS Version 15.0 for Windows (SPSS Inc., Chicago, USA).

\section{Results}

Sixteen tumors were located at the extremities, three at the trunk. The tumors diameters ranged from $1 \mathrm{~cm}$ to 38,5 $\mathrm{cm}$. Twelve primary cultures were harvested from primary tumors, 6 from local recurrences, and 1 from a metastatic tumor. The majority of tumors were high grade (G2-3); only 4 were diagnosed low grade (G1). Atypical lipoma or highly differentiated liposarcoma was the most common histological subentity $(\mathrm{n}=7)$ followed by dedifferentiated $(\mathrm{n}=4)$ and pleomorphic $(\mathrm{n}=4)$, myxoid/rundcell $(\mathrm{n}=3)$ and myxoid $(\mathrm{n}=1)$ liposarcoma. All low grade tumors were diagnosed as atypical lipoma, whereas 3 atypical lipomas were categorized as G2 tumors because of aggressive growth or localized areas of dedifferentiation. The other subentities were all categorized as high grade tumors (G2-3). A summary of the patients' data is given in table 1.

Hierarchical clustering of expression profiles from untreated samples did not clearly separate according to histological subtype or grading, but revealed two major branches, which showed some enrichment for G3 (left) and G2 tumors (right) (fig. 1).

According to the number of differentially expressed genes $\mathrm{n}$ after incubation with doxorubicin, the 19 liposarcomas were categorized into high $(\mathrm{n}>2000)$, intermediate $(100$ $<\mathrm{n}<1000)$ and low responders $(\mathrm{n}<100)$. All poorly differentiated (G3) tumors were high responders; G2 tumors were predominantly intermediate responders; and, most of the G1 tumors were low responders. A heatmap of all differentially expressed genes after $24 \mathrm{~h}$ of doxorubicin tratment shows heterogeneous response patterns (fig. 2).

Correlating the overall expression changes with the histological subtype showed that most of the atypical lipomas were low responders (5 low, 1 medium, 1 high), dedifferentiated were predominantly medium responders (3 medium, 1 high), most myxoid/roundcell and myxoid liposarcomas as well as the pleomorphic liposarcomas were high responders ( 3 high, 1 medium each). The high grade sarcomas (G3) clustered closely together.

The alteration of gene expression related to apoptotic pathways correlated to the categorisation given above. Low responders also did also not respond with relevant gene expression changes of "apoptosis genes" whereas the high responders showed a significantly different gene expression profile concerning apoptosis related genes compared to the untreated control. In all, we found 464 genes with expression changes that are related to apoptotic pathways. The single genes that were differentially expressed in the medium and high responder group only partly overlapped with the low responder group. The heterogeneity of the response patterns of apoptotis related genes is illustrated in figure 3 .

Although the diversity of changes in gene expression was large, some apoptosis related genes showed similar expression changes in the tumor samples, especially the high grade tumors (G2 and G3) or high responders. Figure 4 focus on expression changes in these genes. The apoptosis related genes most often affected by doxorubicin treatment are mentioned below. Due to their large number, we only refer to the genes that were differentially (up- or 


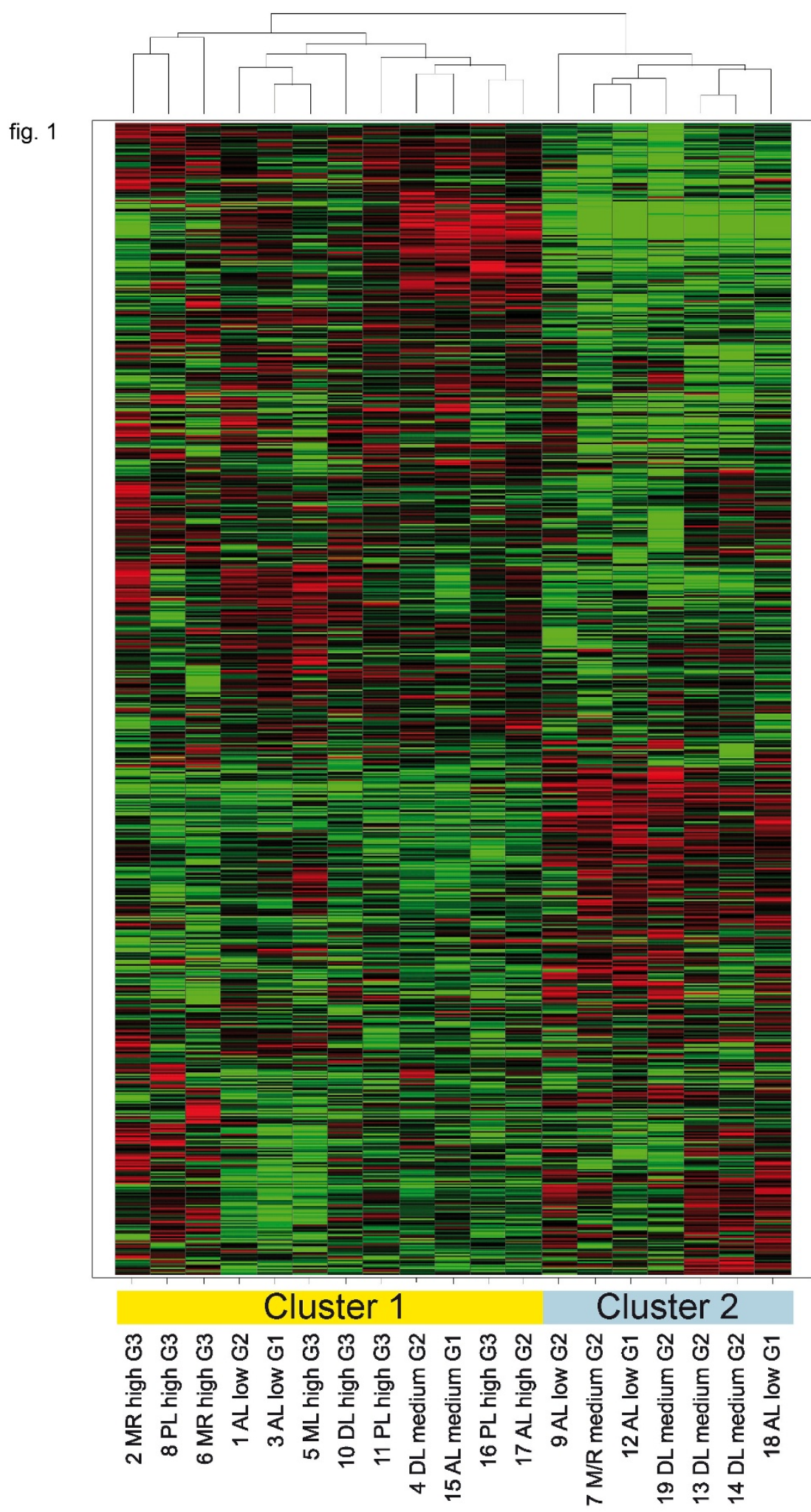

Figure I (see legend on next page) 
Figure I (see previous page)

Unsupervised hierarchical cluster analysis of the 19 primary tumor cell cultures without doxorubin treatment. Gene signal intensities were normalized to the mean signal of all samples, log2 transformed and subjected to hierarchical clustering (UPGMA, Spotfire) and correlation as a similarity measure. Horizontal rows represent individual genes; vertical columns represent individual samples. Black indicates average signal intensity, brightest red $\geq 4$-fold up-regualtion, brightest green $\geq 4$ fold down-regulated gene expression relative to the mean. Only probesets receiving P detection calls in 6 or more samples and a stander deviation of normalized signals $>0.2$ were considered. (7239 retained). The dendogram at the top of the matrix indicates the degree of similarity between tumor samples (the higher the dendogramm, the lower the similarity). Two major clusters were identified as indicated. MR: Myxoid/Roundcell Liposarcoma, PL: Pleomorphic Liposarcoma, AL: Atypical Lipoma, ML: Myxoid Liposarcoma, DL: Dedifferentiated Liposarcoma, low: low responder group, medium: medium responder group, high: high responder group.

down-) regulated in more than $50 \%$ of the probes (samples). Some of the genes that were found up-regulated in the majority of the probes (tumors) could be found down-regulated in some other samples and vice versa. The heatmaps provided illustrate the similarity of the expression of these selected genes in correlation to responder group, grading, and histological subtype (fig. 4. The intrinsic and the extrinsic apoptotic pathway, as well as transcription factors and genes, so far only marginally associated with apoptotic pathways. A summary of the genes and their expression changes is given in table 2 and 3.

The results of the microarray analysis were validated using rtPCR. The general Pearson correlation of the expression changes measured in all selected genes in the tumor probes was high (0.913). The correlation coefficients for the single candidate genes are given in table 4 .

\section{Discussion}

Gene expression profiling has already been helpful in categorizing distinct subtypes of sarcomas by profile clustering [33-35] and identifying subtype specific changes in gene expression in liposarcoma, e.g. abnormal expression of cell cycle regulators in FUS-DDIT3 carrying liposarcomas [34,36-43] and even provided potential targets for new therapeutic agents like important mediators in cell cycle regulation, e.g. MDM2 [44-48].

Gene expression profiling studies on liposarcomas have already shown that this entity presents a somewhat similar expression pattern with malignant fibrous histiocytoma and leimyosarcoma $[31,49]$ and that highly differentiated lesions cluster with lipoma whereas the dedifferentiated tumors cluster with myxoid/round cell liposarcomas [50]; however no clear correlation between expression patterns and histological subtype could be detected [37]. Another difficulty in the assessment of gene expression profiles is the inter- and intra-tumoral heterogeneity. Several subtypes with different expression patterns and histologic features can often be found within one same tumor $[51,52]$.
Liposarcomas are classified into several types based on histological findings and cytological aberrations - well differentiated (atypical lipoma), dedifferentiated, myxoid, round cell tumors and pleomorphic. The risk of distant metastasis grows with the grading of the lesion to up to $75 \%$ in pleomorphic sarcoma. Myxoid tumors with a greater than $5 \%$ round cell component, most dedifferentiated, and pleomorphic liposarcomas are considered high grade lesions [4,53-55].

There are no markers to clearly identify liposarcoma cells. S100, CD34, and others may be helpful (as well as cytogenetic techniques) as they can identify aberrations indicating myxoid/round cell sarcoma; however, they cannot identify liposarcoma cells with absolute certainty [56]. In our series, we relied on a proper tumor dissection and preparation of the specimens to ensure, the isolated tissue mainly consisted of liposarcoma cells as previously described by Sreekantaiah et al. [57] and Lehnhardt et al [58], but have to admit that results may be partly falsified by residual tumor stroma cells accidentally co-cultivated within the liposarcoma samples.

Liposarcoma cells showed diverse gene expression patterns before and after incubation with doxorubicin. Tumors of the same histologic subgroup did not cluster together concerning their overall gene expression. The correlation of the number of differentially regulated genes to the tumor grading, and, to a lesser extent, to the histological subgroup after doxorubicin incubation, may be caused by the tumor associated up-regulation of cell metabolism and the therefore greater effect of any interference. The overall expression patterns and the ones of the apoptosis related genes were also very heterogenous (fig. $2,3)$. This finding is concordant to the results of other studies with soft tissue sarcoma cells [59] and may partly be explained by the known inter- and intratumoral heterogeneity in soft tissue sarcomas $[51,60]$.

Interestingly the myxoid and the myxoid/round cell liposarcomas clustered together in figure 2 and 3 except from the tumor 7 that was pre-treated with chemotherapy. 


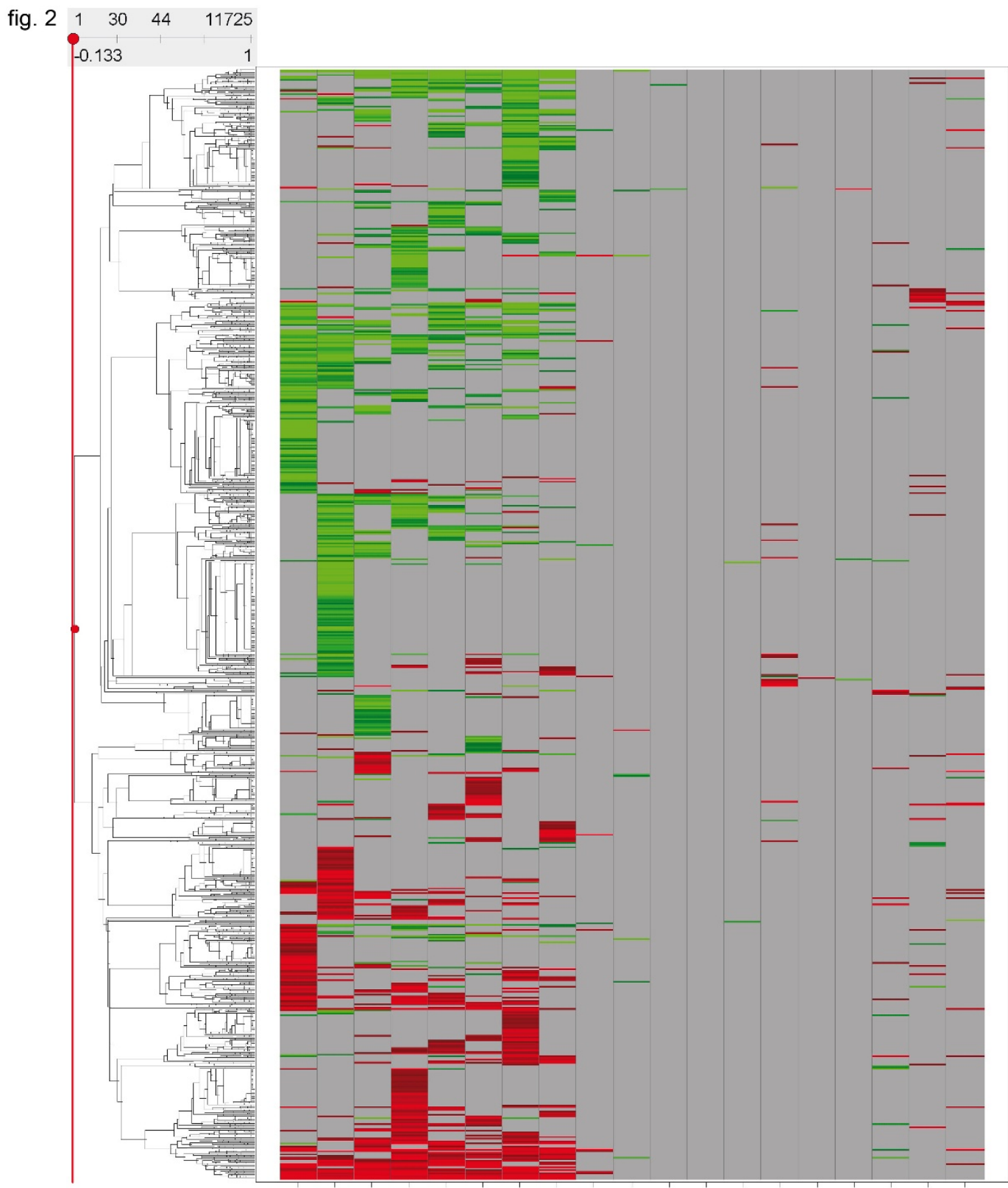

Ґ

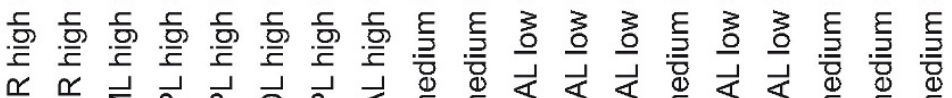

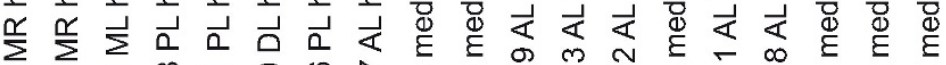

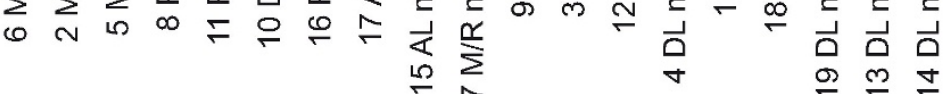

Figure 2 (see legend on next page) 
Figure 2 (see previous page)

Heatmap of total gene expression changes and cluster analysis after incubation with doxorubicin for $\mathbf{2 4} \mathbf{h}$. Horizontal rows represent individual genes; vertical columns represent individual samples. Color range: Brightest red (Change call increased (change p-value < 0.002) and Signal Log Ratio > I): SLR = >2 (4× or higher), Black: SLR = 0 (no change); not visible as a consequence of the filtering process, Brightest green (Change call decreased (change p-value $>0.998$ ) and Signal Log Ratio < $-I)$ : SLR < -2 (0.25x or smaller). Grey: no value (requirements for a reliably measured target not met). Calculated in Affymetrix comparison analysis (MAS5.0 algorithm) and at least one present call in the two síngle array analyses compared in the comparison analysis. The dendogram at the left side indicates the degree of similarity among the selected genes according to their expression patterns (the higher the dendogramm, the lower the similarity). MR: Myxoid/Roundcell Liposarcoma, PL: Pleomorphic Liposarcoma, AL: Atypical Lipoma, ML: Myxoid Liposarcoma, DL: Dedifferentiated Liposarcoma, low: low responder group, medium: medium responder group, high: high responder group.

If that is a coincidence or may be interpreted as a kind of selectional process that could have eliminated the high grade parts of the tumor leaving the residual to cluster closer to the low grade sarcomas can not be determined.

The predescribed low clinical response rates of low grade sarcoma correlate to our findings that low grade liposarcoma, especially atypical lipoma, showed almost no response to doxorubicin on gene expression level [61]. However, some expression changes in response to doxorubicin treatment, observed especially in the high responder and in the high grade group were similar and are focussed on the figure 4. According to the large number of apoptosis related genes, we identified the first five ones that were differentially expressed in more than $50 \%$ of the samples and limit further explanation to these with special reference to apoptotic function in sarcoma or previous reports concerning doxorubicin treatment, although the understanding of their exact functions is limited. The up-regulated genes beyond the mentioned five are summarized in table 5 .

\section{Up-regulated genes}

As previously shown, doxorubicin could overcome TRAIL resistance in a variety of sarcoma cell lines. An up-regulation of the TRAIL-R2, increasing the susceptibility to apoptosis inducing agents such as TRAIL, may be a possible explanation [62-65], as we found the Trail receptor 2 gene expression increased in 15 probes.

The second most frequently up-regulated gene was cyclindependent kinase inhibiton 1A (CDKN1A), a downstream target of $p 53$, has has already been shown to be involved in cell cycle arrest and apoptosis induction by doxorubicin in sarcoma cells. CDKN1A can act as apositive regulator of senescence-like terminal proliferation arrest, but its function seems neither sufficient nor absolutely required for a treatment response to doxorubicin in tumor cells, especially soft tissue sarcoma [66-70].

GADD45A, a potent inhibitor of the c-Jun N-terminal kinase (JNK) cascade and NFKBIA, inhibits transcription factors associated with tumor growth [71-74] and was upregulated by doxorubicin in 12 probes. In a variety of soft tissue sarcoma cell lines GADD45A was found to increase cell cycle arrest and apoptosis $\{\mathrm{Zhu}, 2008 \# 165\}$. For rhabdomyosarcoma, increased GADD45A has previously been associated with less aggressive tumor behaviour [75].

FAS, a member of the tumor necrosis factor receptor family, seems to be an important mediator in doxorubicin induced apoptosis. Its effects were shown to be dependant on metalloproteinases in soft tissue sarcoma and Ewing sarcoma. These metalloproteinases have been associated with aggressive tumor behaviour and may promote invasiveness and the occurrence metastasis of malignant cells [76-78].

Another member of the TNF receptor superfamily, CD40, was also up-regulated by doxubicin in our experiments. To the authors' knowledge, CD40 has not yet been associated with doxorubicin treatment in liposarcoma, but its expression in soft tissue sarcoma was associated with an unfavourable outcome [79], whereas Lodge et al. could show a beneficial effect of antibody mediated CD40 activation in elimination of fibrosarcoma in nude mice [80].

\section{Down-regulated genes}

Among the down-regulated genes related to apoptotic pathways $C D 14$, a receptor marking apoptotic cells was found in 8 probes. Increased $C D 14$ has been associated with apoptosis induction and cell clearance, especially mediated by macrophages, but is expressed by a variety of other cells too [81-83]. Its role in terms of cell death mediation in sarcoma cells has not yet been examined, therefore interpretation of this finding remains difficult.

TIA-1, which encodes an RNA-binding protein with translation-regulatory functions has already been reported to be up-regulated in tumor specimens post-treatment with TNF alpha in soft tissue sarcomas. It was further hypothesized that TIA-1 could mediate death receptor mediated apoptosis in soft tissue sarcoma and that its overexpres- 
fig. 3

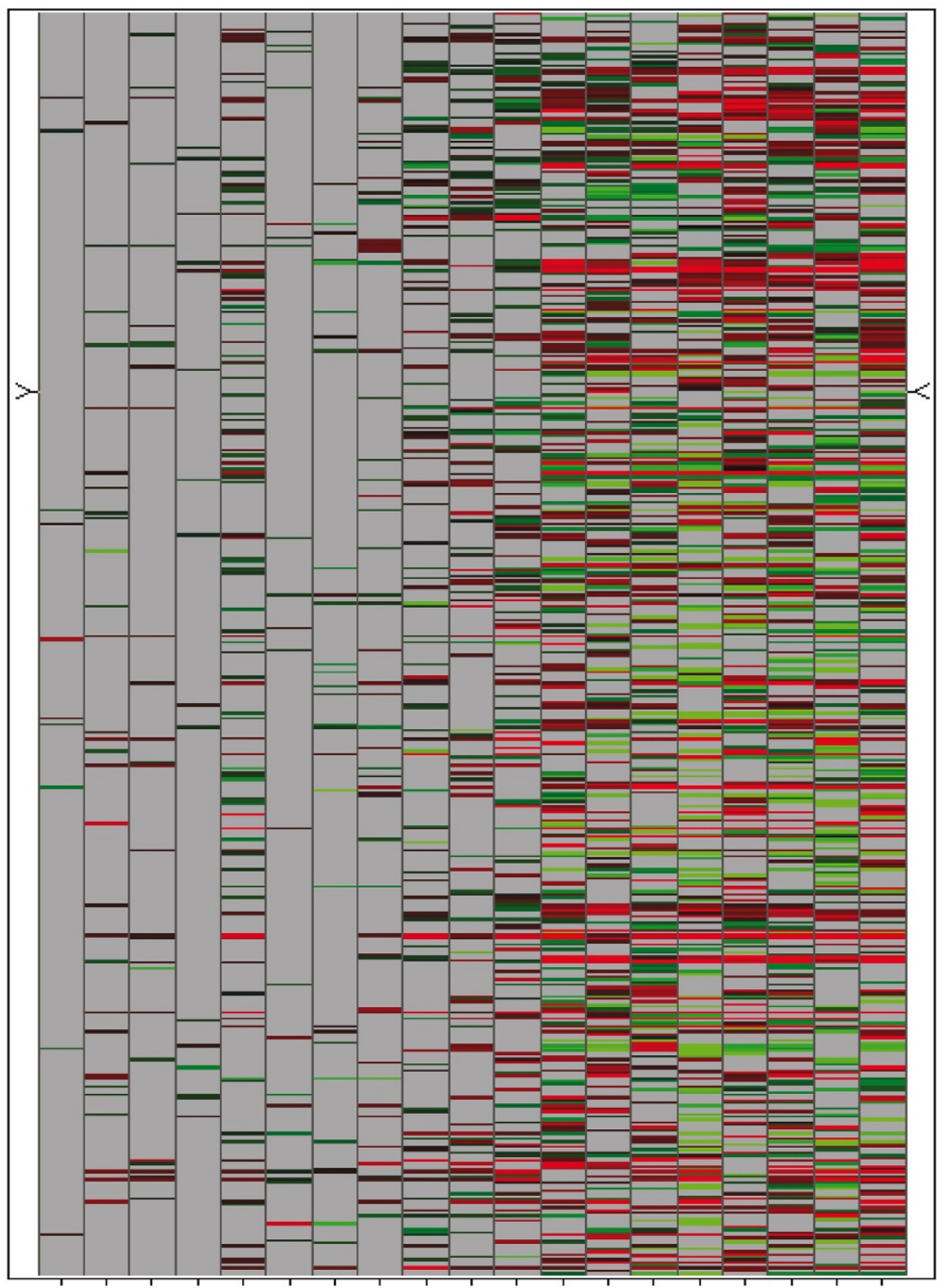

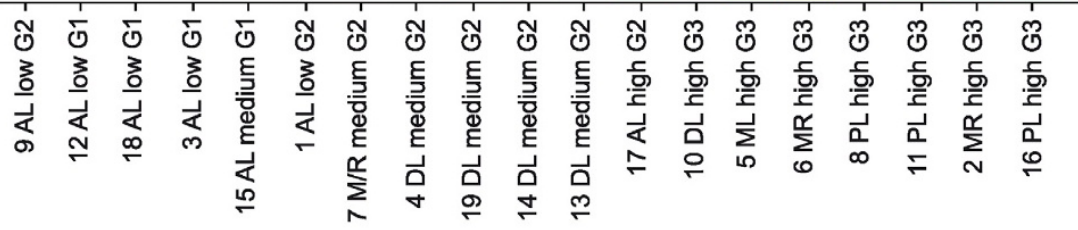

\section{Figure 3}

Heatmap of expression changes of genes related to apoptotic pathways after incubation with doxorubicin for $24 \mathbf{h}$. Horizontal rows represent individual genes; vertical columns represent individual samples (left to right: low responders to high responders). Color range: Brightest red (Change call increased (change p-value < 0.002) and Signal Log Ratio > I): SLR $=>2$ ( $4 \times$ or higher), Black: SLR $=0$ (no change); not visible as a consequence of the filtering process, Brightest green (Change call decreased (change p-value $>0.998$ ) and Signal Log Ratio < - I): SLR < -2 (0.25x or smaller). Grey: no value (requirements for a reliably measured target not met). Calculated in Affymetrix comparison analysis (MAS5.0 algorithm) and at least one present call in the two síngle array analyses compared in the comparison analysis. 
Table 2: Summary of the genes that were up-regulated by doxorubicin treatment, including the log ratios

\begin{tabular}{|c|c|c|c|c|c|c|}
\hline $\begin{array}{l}\text { Samples with increased } \\
\text { expression (n) }\end{array}$ & Gene symbol & Mean log ratio & Range of log ratio & $\begin{array}{l}\text { Samples with decreased } \\
\text { expression }(n)\end{array}$ & Mean log ratio & (Range of) log ratio \\
\hline 15 & TNFRSFIOB & 1.96 & $0.4 I / 4.49$ & 0 & - & - \\
\hline 12 & CDKNIA & 1.85 & $0.59 / 4.10$ & I & - & -0.99 \\
\hline 12 & GADD45A & 1.44 & $0.58 / 2.88$ & I & - & -0.59 \\
\hline 12 & FAS & 1.36 & $0.27 / 3.87$ & I & - & -0.28 \\
\hline 12 & CD40 & 0.94 & $0.39 / 2.11$ & 0 & - & - \\
\hline 11 & PAWR & 1.16 & $0.33 / 2.51$ & I & - & -1.25 \\
\hline 11 & TNFAIP3 & 2.16 & $0.23 / 3.67$ & 0 & - & - \\
\hline 10 & NFKBIA & 2.04 & $0.43 / 3.34$ & 2 & -0.57 & $-0.45 /-0.69$ \\
\hline 10 & IER3 & 3.81 & $0.71 / 6.08$ & 2 & -0.60 & $-0.36 /-0.84$ \\
\hline 10 & PSENI & 0.84 & $0.23 / 1.61$ & 2 & -0.46 & -0.46 \\
\hline 10 & RIPK2 & 2.02 & $0.42 / 3.65$ & 2 & -0.60 & $-0.46 /-0.74$ \\
\hline 10 & PEAI 5 & 0.61 & $0.23 / 0.96$ & I & - & -0.68 \\
\hline 10 & BCL2AI & 2.18 & $1.03 / 5.08$ & I & - & -0.98 \\
\hline 10 & NGFB & 3.06 & $0.40 / 5.80$ & I & - & -1.12 \\
\hline 10 & BIRC3 & 2.06 & $0.63 / 3.23$ & I & - & -0.93 \\
\hline 10 & CD44 & 1.57 & $0.26 / 3.09$ & 1 & - & -0.56 \\
\hline 9 & MCLI & 1.46 & $0.67 / 2.08$ & 3 & -0.65 & $-0.26 /-1.21$ \\
\hline 9 & HSPA9 & 1.25 & $0.46 / 1.95$ & 2 & -0.50 & $-0.21 /-0.79$ \\
\hline 9 & BTGI & 0.77 & $0.31 / 1.50$ & I & - & -1.06 \\
\hline 9 & HSP90BI & 0.80 & $0.21 / 1.10$ & 0 & - & - \\
\hline 9 & SQSTMI & 2.03 & $0.27 / 3.23$ & 0 & - & - \\
\hline 9 & PPPIRI5A & 3.16 & $0.65 / 4.40$ & 0 & - & - \\
\hline 9 & IRFI & 1.38 & $0.60 / 2.94$ & 0 & - & - \\
\hline 9 & CYCS & 0.82 & $0.34 / 1.37$ & 0 & - & - \\
\hline 9 & MDM2 & 1.76 & $0.33 / 3.58$ & 0 & - & - \\
\hline
\end{tabular}

Negative log ratios stand for down-regulated genes.

sion might sensitize endothelial cells to proapoptotic stimuli present in the tumor microenvironment and enhance NK cell cytotoxic activity against cancer cells [84].

YWHAH, or 14-3-3 eta, is a member of the dimeric 14-33 family of signal transduction proteins that specifically binds to phosphorylated serine on a variety of signalling molecules, such as Bcl-2, MDMX, and Bax, thereby promoting cell survival and acting antiapoptotic in several tumor cells [85-87]. On the other hand, it is supposed to be associated with tumorigenesis through its binding interaction with gremlin1 [88]. Therefore the issue of further studies should be awaited before interpreting this finding.

PPP3CA (CCN1/Cyr61) is susceptible to various growth factors and promotes cell proliferation, adhesion, and differentiation and plays important roles in angiogenesis. Additionally, PPP3CA has been associated with tumorigenesis. It was reported that PPP3CA exerts its functions via interacting with integrins as well as heparan sulfate proteoglycan. By activating NF-kappaB and tyrosine kinase signalling pathways, PPP3CA is not only able to control cell growth, but also induce or suppress apoptosis in a cell type-specific manner $[89,90]$. To the authors' knowledge, it has so far not been reported in context with liposarcoma or doxorubicin treatment.

Integrin B2 (ITGB2) is known to play a role in mediating apoptosis [91] and chemotherapy resistance. Although it is widely attributed to white blood cells, it is also expressed in a variety of other benign and malignant cells and seems to play a major role in cell invasion and migration [92].

\section{Conclusion}

In summary, pro- and antiapoptotic genes were found upas well as down-regulated with a dominance of up-regulation of proapoptotic genes. The heterogeneous expression profiles reflect the heterogeneous reaction of liposarcomas to doxorubicin therapy. A lot of genes we found differentially expressed have not yet been associated with apoptosis in liposarcoma or doxorubicin treatment. Therefore it is not possible to relate our findings to other studies. Our study shows that the low clinical response rates of highly differentiated liposarcoma correlate to minimal changes in the expression patterns and that only high grade tumors, especially myxoid/roundcell and pleomorphic tumors, respond to doxorubicin on gene expression level. In most cases, this response seems to be 
Table 3: Summary of the genes that were down-regulated by doxorubicin treatment, including the log ratios

\begin{tabular}{|c|c|c|c|c|c|c|}
\hline $\begin{array}{l}\text { Samples with decreased } \\
\text { expression (n) }\end{array}$ & Gene symbol & Mean log ratio & Range of log ratio & $\begin{array}{l}\text { Samples with increased } \\
\text { expression }(n)\end{array}$ & Mean log ratio & Range of log ratio \\
\hline II & CDI4 & -2.99 & $-0.27 /-5.38$ & 0 & - & - \\
\hline 10 & TIAI & -0.68 & $-0.24 /-1.05$ & 1 & - & 0.77 \\
\hline 10 & YWHAH & -0.72 & $-0.27 /-1.80$ & 0 & - & - \\
\hline 10 & PPP3CA & -0.69 & $-0.34 /-1.14$ & 0 & - & - \\
\hline 10 & ITGB2 & -2.87 & $-0.58 /-5.11$ & 0 & - & - \\
\hline 9 & PDGFRA & -1.32 & $-0.42 /-3.30$ & 2 & 2.62 & $1.21 / 4.03$ \\
\hline 9 & RASAI & -0.93 & $-0.42 /-1.17$ & 0 & - & - \\
\hline 8 & LDHB & -0.60 & $-0.32 /-1.25$ & 2 & 1.11 & $0.64 / 1,58$ \\
\hline 8 & CSFIR & -3.05 & $-0.63 /-5.08$ & 0 & - & - \\
\hline 8 & RARA & -0.95 & $-0.51 /-1.23$ & 0 & - & - \\
\hline 7 & ANXA4 & -1.10 & $-0.64 /-1.16$ & 4 & 1.37 & $0.84 / 2.33$ \\
\hline 7 & CTSB & -0.93 & $-0.23 /-1.97$ & 3 & 0.94 & $0.82 / 1.13$ \\
\hline 7 & DAPKI & -1.35 & $-0.59 /-2.07$ & 2 & 1,40 & $1.19 / 1.60$ \\
\hline 7 & CASPI & -1.69 & $-0.71 /-2.90$ & 2 & 1.44 & $0.97 / 1.90$ \\
\hline 7 & PRFI & -1.68 & $-0.54 /-3.68$ & 2 & 0.79 & $0.67 / 0.91$ \\
\hline 7 & EPHB4 & -1.30 & $-0.68 /-2.34$ & 1 & - & 0.30 \\
\hline 7 & $\mathrm{HCK}$ & -1.79 & $-0.39 /-3.65$ & 1 & - & 1.08 \\
\hline 7 & ESD & -0.76 & $-0.44 /-0.95$ & 1 & - & 0.36 \\
\hline 7 & DHCR24 & -1.97 & $-0.75 /-4.34$ & 0 & - & - \\
\hline 7 & PPPICB & -0.99 & $-0.62 /-1.56$ & 0 & - & - \\
\hline 7 & MYOI8A/TIAFI & -1.23 & $-0.67 /-2.02$ & 0 & - & - \\
\hline 7 & BIRC5 & -2.95 & $-1 .|7 /-4.9|$ & 0 & - & - \\
\hline 7 & PDGFRB & -1.28 & $-0.61 /-2.26$ & 0 & - & - \\
\hline 7 & ATG5 & -1.39 & $-0.61 /-3.19$ & 0 & - & - \\
\hline 7 & DOCKI & -0.86 & $-0.40 /-1.23$ & 0 & - & - \\
\hline 7 & PTPNI3 & -1.97 & $-0.69 /-3.17$ & 0 & - & - \\
\hline 7 & BTK & -1.78 & $-0.39 /-3.28$ & 0 & - & - \\
\hline 7 & SYK & -4.26 & $-0.34 /-8.06$ & 0 & - & - \\
\hline
\end{tabular}

Positive log ratios stand for up-regulated genes. 
4a)

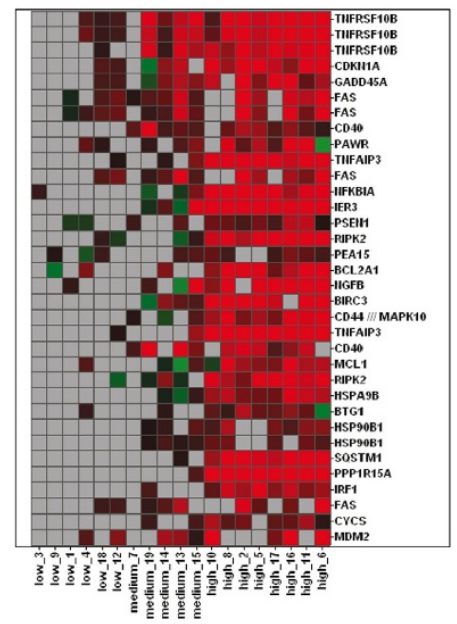

5a)

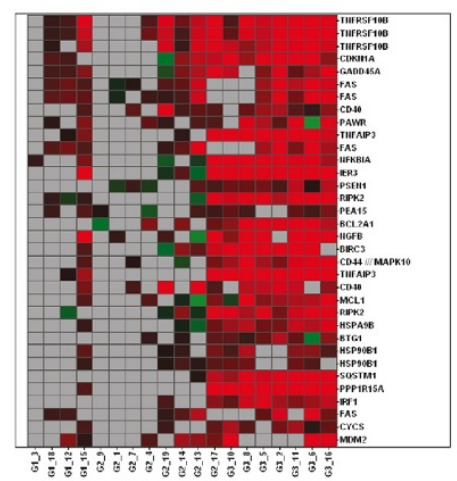

6a)

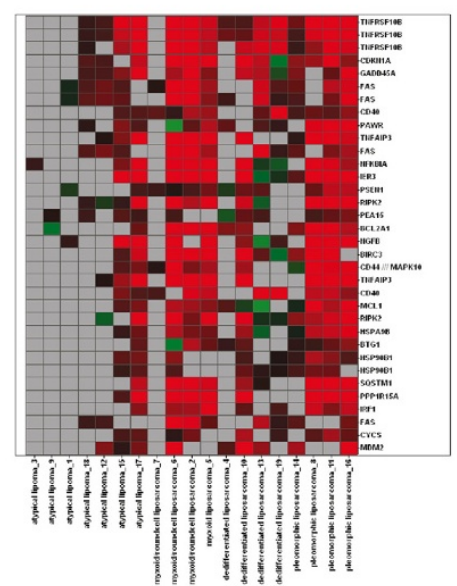

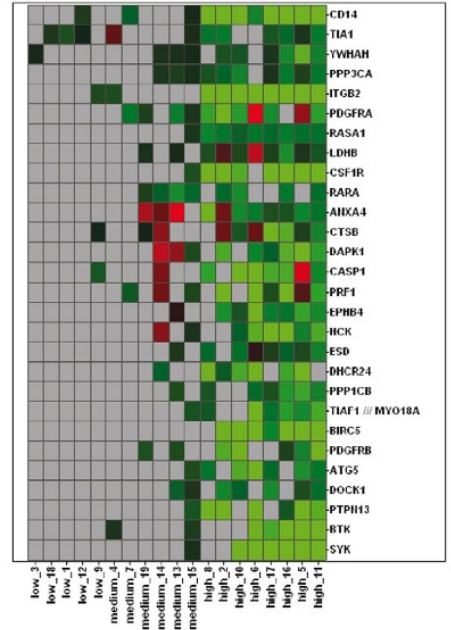

$4 b)$

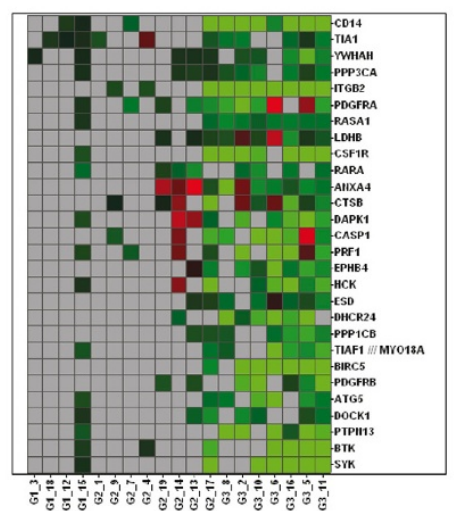

$5 b)$

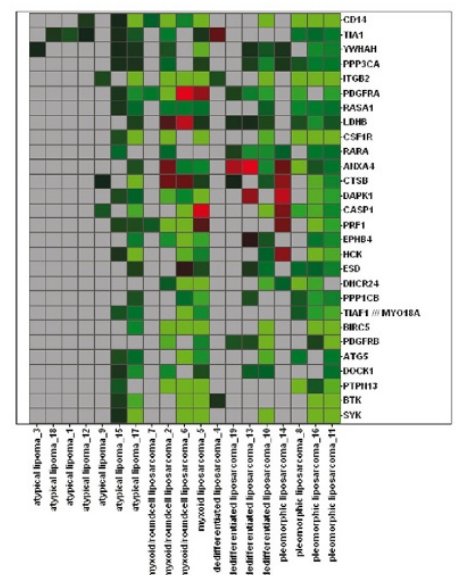

$6 b)$

Figure 4

Heatmaps of expression changes of selected genes associated with apoptotic pathways after incubation with doxorubicin for 24 h ordered by responder group (5 a,b), grading (6 a,b), and histologic subtype (7 a/b). Expression changes as determined by comparison analysis were considered only if the probeset showed at least one P detection in untreated/treated sample pairs. Excluded expression changes are shown in grey. Only probesets with expression changes in 7 or more samples are given. Horizontal rows represent individual probesets. Vertical columns represent individual samples (left to right: low responders to high responders); gene symbols are indicated to the right. Gene expression changes are indicated by a continuous scale; the brightest red indicating $\geq 4$-fold up-regulation; and, brightest green $\geq 4$-fold down-regulated gene expression relative to the untreated control sample. 
Table 5: Summary of genes beyond the ones already mentioned in the text that were found to be up-regulated by doxorubicin treatment in more than $50 \%$ of the probes.

\begin{tabular}{|c|c|c|c|c|}
\hline Gene symbol & Gene name & Probes upregulated & Additional information & Apoptotic function \\
\hline PAWR & $\begin{array}{l}\text { PRKC (protein kinase C) apoptosis } \\
\text { WTI (Wilms tumor gene) regulator protein }\end{array}$ & 11 & $\begin{array}{l}\text { STS with high WTI mRNA expression levels have } \\
\text { poorer outcome than those with low levels }[89,90] \text {. } \\
\text { Ecteinascidin that has been shown to be effective } \\
\text { against STS also increases expression of PAWR [92]. } \\
\text { PAWR inhibits the PKC (atypical protein kinase)-NF- } \\
\text { (kappa)B (nuclear factor-(kappa)B)-XIAP pathway [9I]. }\end{array}$ & proapoptotic \\
\hline TNFAIP3 & tumor necrosis factor, alpha-induced protein 3 & 11 & $\begin{array}{l}\text { TNFAIP3 down-regulates the TNF- } \alpha \text {-induced NFKB } \\
\text { signalling pathway }[93,94] \text {. }\end{array}$ & antiapoptotic \\
\hline NFKBIA & $\begin{array}{l}\text { nuclear factor of kappa light polypeptide gene } \\
\text { enhancer in B-cells inhibitor alpha }\end{array}$ & 10 & $\begin{array}{l}\text { The doxorubicin analogon DA- } 125 \text { reduces } \\
\text { proliferation in HTI } 080 \text { fibrosarcoma cells through a } \\
\text { NFKB dependent pathway [ } 96,97] \text {. } \\
\text { MDM2 (upregulated in } 9 \text { samples in our series) is } \\
\text { overexpressed in several liposarcoma subtypes [58] and } \\
\text { increases NFKB activity in a p53 dependent manner and } \\
\text { thereby leads to doxorubicin resistance [98]. }\end{array}$ & proapoptotic/antiapoptotic \\
\hline IER3 & immediate early response 3 & 10 & $\begin{array}{l}\text { IER3 function is increased by p } 53 \text {, that is induced by } \\
\text { doxorubicin. IER3 is involved in cell cycle arrest and } \\
\text { programmed cell death }[99,100] \text {. }\end{array}$ & proapoptotic \\
\hline PSENI & presenilin I & 10 & Effects are mediated via $\mathrm{Bcl}-2$ interaction $[\mathrm{IO} \mid]$ & proapoptotic \\
\hline RIPK2 & receptor-interacting serine-threonine kinase 2 & 10 & $\begin{array}{l}\text { RIPK2 is cell death inducing and NFKB activating, via } \\
\text { caspase I activation }[102,103] \text {. }\end{array}$ & proapoptotic \\
\hline PEAI5 & phosphoprotein enriched in astrocytes 15 & 10 & $\begin{array}{l}\text { RPEAI5 is regulating caspase- } 3 \text { function in epidermal } \\
\text { cells [104], but has not yet been associated with } \\
\text { doxorubicin treatment or apoptosis in sarcoma cells. }\end{array}$ & antiapoptotic \\
\hline BCL2AI & $\begin{array}{l}\mathrm{BCL2} \text { (B-cell CLL/lymphoma 2)-related protein } \\
\mathrm{Al}\end{array}$ & 10 & $\begin{array}{l}\text { BCL2AI stabilizes the mitochondrial membrane } \\
{[105,106] .}\end{array}$ & antiapoptotic \\
\hline NGFB & nerve growth factor, beta polypeptide & 10 & $\begin{array}{l}\text { NGF reduces apoptosis induced by chemotherapeutics } \\
\text { in sarcoma cells [109]. }\end{array}$ & antiapoptotic \\
\hline BIRC3 & baculoviral IAP repeat-containing 3 & 10 & $\begin{array}{l}\text { BIRC3 is associated with chemotherapy resistance in } \\
\text { Ewing sarcoma, rhabdomyosarcoma [II } 10] \text { and prostatic } \\
\text { cancer [III]. }\end{array}$ & antiapoptotic \\
\hline CD44 & cell surface glycoprotein CD44 & 10 & $\begin{array}{l}\text { CD44 is a proapoptotic factor in FAS mediated } \\
\text { apoptosis in sarcoma cells }\left[\begin{array}{ll}1 & 12\end{array}\right] \text {, but is also connected } \\
\text { to cancer drug resistance }\left[\begin{array}{ll}1 & 13\end{array}\right] \text {. } \\
\text { CD44 has successfully been used as a target for } \\
\text { liposomal encapsuled doxorubicin [ } 114] \text {. }\end{array}$ & proapoptotic/antiapoptotic \\
\hline
\end{tabular}


Table 4: Pearson coefficient calculated for the candidate genes describing the correlation of the gene expression changes measured microarray and rtPCR.

\begin{tabular}{lc}
\hline Gene symbol & Pearson coefficient \\
\hline CD40 & 0.945 \\
CDKNIA & 1.000 \\
FAS & 0.813 \\
GADD45A & 0.848 \\
ITGB2 & 0.999 \\
NFKBIA & 0.882 \\
PAWR & 0.913 \\
PPP3CA & 0.638 \\
TNFAIP3 & 0.997 \\
TNFRSFIOB & 0.998 \\
YWHAH & 0.370 \\
\hline
\end{tabular}

based on an increase of the extrinsic pathway such as TRAIL Receptor 2 and FAS but also members of the intrinsic pathway such as BCL2A1 were found to be differentially expressed. Interestingly several factors (NFKBIA, GADD45A, RIPK2, and PAWR) point to the NFKB transcriptional factor as possible mediator of doxorubicin effects.

Our results indicate that gene expression profiling may be a promising approach to improve the understanding of the diverse modes of programmed cell death in liposarcoma following doxorubicin treatment and can provide a molecular basis for new chemotherapeutic strategies.

\section{Competing interests}

The authors declare that they have no competing interests.

\section{Authors' contributions}

$\mathrm{AD}$ developed the study design, coordinated the work, interpreted the data and prepared the manuscript. LKH carried out and interpreted the microarrays. AMC carried out statistical analyses, have given substantial contribution to conception and design as well manuscript preparation. OM improved the study design and corrected the manuscript. HJ prepared the figures and gathered patients data. HHH was helpful in preparing the manuscript and conceived the work. HUS was helpful in preparing the manuscript and conceived the work. ML carried out cell culture and developed the idea, study design and conceived the work

\section{Acknowledgements}

We thank Amanda Daigeler for her formal English revision of the manuscript.

\section{References}

I. Lehnhardt M, Kuhnen C, Drucke D, Homann HH, Joneidi Jafari H, Steinau HU: [Liposarcoma of the extremities: recent developments in surgical therapy - analysis of 167 patients]. Chirurg 2004, 75(I2): I 182-1190.
2. Kuhnen C, Lehnhardt M, Steinau HU, Muller KM: [liposarcoma. Aspects of pathomorphology - an analysis of 209 tumos]. Chirurg 2004, 75(1 2): II I I-I I 58.

3. Mack TM: Sarcomas and other malignancies of soft tissue, retroperitoneum, peritoneum, pleura, heart, mediastinum, and spleen. Cancer 1995, 75( I Suppl):2 I I-244.

4. Dei Tos AP: Liposarcoma: new entities and evolving concepts. Ann Diagn Pathol 2000, 4(4):252-266.

5. Dalal KM, Kattan MW, Antonescu CR, Brennan MF, Singer S: Subtype specific prognostic nomogram for patients with primary liposarcoma of the retroperitoneum, extremity, or trunk. Ann Surg 2006, 244(3):38I-39I.

6. Mentzel T, Fletcher CD: Lipomatous tumours of soft tissues: an update. Virchows Arch 1995, 427(4):353-363.

7. Hartmann JT, Patel S: New drug developments for patients with metastatic soft tissue sarcoma. Curr Oncol Rep 2005, 7(4):300-306.

8. Jones RL, Fisher C, Al-Muderis O, Judson IR: Differential sensitivity of liposarcoma subtypes to chemotherapy. Eur J Cancer 2005, 4 I ( I 8):2853-2860.

9. Gortzak E, Azzarelli A, Buesa J, Bramwell VH, van Coevorden F, van Geel AN, Ezzat A, Santoro A, Oosterhuis JW, van Glabbeke M, et al.: A randomised phase II study on neo-adjuvant chemotherapy for 'high-risk' adult soft-tissue sarcoma. Eur J Cancer 200I, 37(9): 1096-1 I 103.

10. Frustaci S, Gherlinzoni F, De Paoli A, Bonetti M, Azzarelli A, Comandone A, Olmi P, Buonadonna A, Pignatti G, Barbieri E, et al.: Adjuvant chemotherapy for adult soft tissue sarcomas of the extremities and girdles: results of the Italian randomized cooperative trial. J Clin Oncol 200I, 19(5): I238-I247.

II. Eilber FC, Eilber FR, Eckardt J, Rosen G, Riedel E, Maki RG, Brennan MF, Singer S: The impact of chemotherapy on the survival of patients with high-grade primary extremity liposarcoma. Ann Surg 2004, 240(4):686-695.

12. Meta-analysis-Group: Adjuvant chemotherapy for localised resectable soft-tissue sarcoma of adults: meta-analysis of individual data. Sarcoma Meta-analysis Collaboration. Lancet 1997, 350(9092): 1647-1654.

13. Mack LA, Crowe PJ, Yang JL, Schachar NS, Morris DG, Kurien EC, Temple CL, Lindsay RL, Magi E, DeHaas WG, et al:: Preoperative chemoradiotherapy (modified Eilber protocol) provides maximum local control and minimal morbidity in patients with soft tissue sarcoma. Ann Surg Oncol 2005, I 2(8):646-653.

14. Van Glabbeke M, van Oosterom AT, Oosterhuis JW, Mouridsen H, Crowther D, Somers R, Verweij J, Santoro A, Buesa J, Tursz T: Prognostic factors for the outcome of chemotherapy in advanced soft tissue sarcoma: an analysis of 2, 185 patients treated with anthracycline-containing first-line regimens - a European Organization for Research and Treatment of Cancer Soft Tissue and Bone Sarcoma Group Study. J Clin Oncol 1999, I7(I): I50-157.

15. Debatin KM, Krammer PH: Death receptors in chemotherapy and cancer. Oncogene 2004, 23(16):2950-2966.

16. Debatin KM: Apoptosis pathways in cancer and cancer therapy. Cancer Immunol Immunother 2004, 53(3): 153-159.

17. Soengas MS, Alarcon RM, Yoshida H, Giaccia AJ, Hakem R, Mak TW, Lowe SW: Apaf-I and caspase-9 in p53-dependent apoptosis and tumor inhibition. Science 1999, 284(54II): I56-I59.

18. Hostanska K, Vuong V, Rocha S, Soengas MS, Glanzmann C, Saller R, Bodis S, Pruschy M: Recombinant mistletoe lectin induces p53independent apoptosis in tumour cells and cooperates with ionising radiation. Br J Cancer 2003, 88(I I): 1785-I792.

19. Zhan M, Yu D, Lang A, Li L, Pollock RE: Wild type p53 sensitizes soft tissue sarcoma cells to doxorubicin by down-regulating multidrug resistance-I expression. Cancer 200I, 92(6): $1556-1566$.

20. Coley HM: Drug resistance studies using fresh human ovarian carcinoma and soft tissue sarcoma samples. Keio J Med 1997, 46(3): $142-147$.

21. Toffoli G, Frustaci S, Tumiotto L, Talamini R, Gherlinzoni F, Picci P, Boiocchi M: Expression of MDR I and GST-pi in human soft tissue sarcomas: relation to drug resistance and biological aggressiveness. Ann Oncol 1992, 3(1):63-69.

22. Komdeur R, Molenaar WM, Zwart N, Hoekstra HJ, Berg E van den, Graaf WT van der: Multidrug resistance proteins in primary and metastatic soft-tissue sarcomas: down-regulation of $P$ - 
glycoprotein during metastatic progression. Anticancer Res 2004, 24(I):29I-295.

23. Kuhnen C, Muller KM, Steinau HU, Lehnhardt M: [Therapyinduced tumor regression in adult soft tissue sarcomas-morphological findings]. Pathologe 2004.

24. Skubitz KM, Skubitz AP: Differential gene expression in leiomyosarcoma. Cancer 2003, 98(5): $1029-1038$.

25. Hwang RF, Hunt KK: Experimental approaches to treatment of soft tissue sarcoma. Surg Oncol Clin N Am 2003, I2(2):499-52 I.

26. Schofield D, Triche TJ: cDNA microarray analysis of global gene expression in sarcomas. Curr Opin Oncol 2002, I4(4):406-4II.

27. Lehnhardt M, Klein-Hitpass L, Kuhnen C, Homann HH, Daigeler A, Steinau HU, Roehrs S, Schnoor L, Steinstraesser L, Mueller O: Response rate of fibrosarcoma cells to cytotoxic drugs on the expression level correlates to the therapeutic response rate of fibrosarcomas and is mediated by regulation of apoptotic pathways. BMC Cancer 2005, 5:74.

28. Rebbaa A, Zheng X, Chou PM, Mirkin BL: Caspase inhibition switches doxorubicin-induced apoptosis to senescence. Oncogene 2003, 22( I 8):2805-28I I.

29. Rebbaa A, Chou PM, Emran M, Mirkin BL: Doxorubicin-induced apoptosis in caspase-8-deficient neuroblastoma cells is mediated through direct action on mitochondria. Cancer Chemother Pharmacol 200I, 48(6):423-428.

30. Rebbaa A, Chou PM, Mirkin BL: Factors secreted by human neuroblastoma mediated doxorubicin resistance by activating STAT3 and inhibiting apoptosis. Mol Med 200I, 7(6):393-400.

31. Nielsen TO, West RB, Linn SC, Alter O, Knowling MA, O'Connell JX, Zhu S, Fero M, Sherlock G, Pollack JR, et al.: Molecular characterisation of soft tissue tumours: a gene expression study. Lancet 2002, 359(93 | 4): I30|- | 307.

32. Ashburner M, Ball CA, Blake JA, Botstein D, Butler H, Cherry JM, Davis AP, Dolinski K, Dwight SS, Eppig JT, et al.: Gene ontology: tool for the unification of biology. The Gene Ontology Consortium. Nat Genet 2000, 25(I):25-29.

33. West RB, Harvell J, Linn SC, Liu CL, Prapong W, Hernandez-Boussard T, Montgomery K, Nielsen TO, Rubin BP, Patel R, et al.: Apo D in soft tissue tumors: a novel marker for dermatofibrosarcoma protuberans. Am J Surg Pathol 2004, 28(8): 1063-1069.

34. Skubitz KM, Cheng EY, Clohisy DR, Thompson RC, Skubitz AP: Differential gene expression in liposarcoma, lipoma, and adipose tissue. Cancer Invest 2005, 23(2): 105-1I8.

35. Baird K, Davis S, Antonescu CR, Harper UL, Walker RL, Chen $Y$, Glatfelter AA, Duray PH, Meltzer PS: Gene expression profiling of human sarcomas: insights into sarcoma biology. Cancer Res 2005, 65(20):9226-9235.

36. Goransson M, Elias E, Stahlberg A, Olofsson A, Andersson C, Aman $P$ : Myxoid liposarcoma FUS-DDIT3 fusion oncogene induces C/EBP beta-mediated interleukin 6 expression. Int J Cancer 2005, I I 5(4):556-560.

37. Fritz B, Schubert F, Wrobel G, Schwaenen C, Wessendorf S, Nessling M, Korz C, Rieker RJ, Montgomery K, Kucherlapati R, et al.: Microarray-based copy number and expression profiling in dedifferentiated and pleomorphic liposarcoma. Cancer Res 2002 62(II):2993-2998.

38. Italiano A, Cardot N, Dupre F, Monticelli I, Keslair F, Piche M, Mainguene C, Coindre JM, Pedeutour F: Gains and complex rearrangements of the $12 q 13-15$ chromosomal region in ordinary lipomas: the "missing link" between lipomas and liposarcomas? Int J Cancer 2007, I 2 I (2):308-3I5.

39. Bassett MD, Schuetze SM, Disteche C, Norwood TH, Swisshelm K Chen X, Brckner J, Conrad EU 3rd, Rubin BP: Deep-seated, well differentiated lipomatous tumors of the chest wall and extremities: the role of cytogenetics in classification and prognostication. Cancer 2005, 103(2):409-416.

40. Meis-Kindblom JM, Sjogren H, Kindblom LG, Peydro-Mellquist A, Roijer E, Aman P, Stenman G: Cytogenetic and molecular genetic analyses of liposarcoma and its soft tissue simulators: recognition of new variants and differential diagnosis. Virchows Arch 200I, 439(2): |4|-|5|.

41. Sandberg AA: Updates on the cytogenetics and molecular genetics of bone and soft tissue tumors: liposarcoma. Cancer Genet Cytogenet 2004, I 55(I): I-24.

42. Engstrom K, Willen $\mathrm{H}$, Kabjorn-Gustafsson $\mathrm{C}$, Andersson $\mathrm{C}$, Olsson M, Goransson M, Jarnum S, Olofsson A, Warnhammar E, Aman P. The myxoid/round cell liposarcoma fusion oncogene FUS-
DDIT3 and the normal DDIT3 induce a liposarcoma phenotype in transfected human fibrosarcoma cells. Am J Pathol 2006, 168(5): 1642-1653

43. Szymanska J, Virolainen M, Tarkkanen M, Wiklund T, Asko-Seljavaara S, Tukiainen E, Elomaa I, Blomqvist C, Knuutila S: Overrepresentation of I q2 I-23 and I 2q I 3-2 I in lipoma-like liposarcomas but not in benign lipomas: a comparative genomic hybridization study. Cancer Genet Cytogenet 1997, 99(I): 14-18.

44. Fukukawa C, Nakamura Y, Katagiri T: Molecular target therapy for synovial sarcoma. Future Oncol 2005, I(6):805-8I2

45. Ishibe T, Nakayama T, Okamoto T, Aoyama T, Nishijo K, Shibata KR, Shima Y, Nagayama S, Katagiri T, Nakamura Y, et al: Disruption of fibroblast growth factor signal pathway inhibits the growth of synovial sarcomas: potential application of signal inhibitors to molecular target therapy. Clin Cancer Res 2005, I I(7):2702-27I2

46. Lubieniecka JM, Nielsen TO: cDNA microarray-based translational research in soft tissue sarcoma. I Surg Oncol 2005, 92(4):267-27I.

47. Nagayama S, Fukukawa C, Katagiri T, Okamoto T, Aoyama T, Oyaizu $\mathrm{N}$, Imamura M, Toguchida J, Nakamura Y: Therapeutic potential of antibodies against FZD 10, a cell-surface protein, for synovial sarcomas. Oncogene 2005, 24(4I):620I-62I2.

48. Singer S, Socci ND, Ambrosini G, Sambol E, Decarolis $P, W u Y$, O'Connor R, Maki R, Viale A, Sander C, et al.: Gene expression profiling of liposarcoma identifies distinct biological types/ subtypes and potential therapeutic targets in well-differentiated and dedifferentiated liposarcoma. Cancer Res 2007, 67(14):6626-6636

49. Segal NH, Pavlidis P, Antonescu CR, Maki RG, Noble WS, DeSantis D, Woodruff JM, Lewis JJ, Brennan MF, Houghton AN, et al.: Classification and subtype prediction of adult soft tissue sarcoma by functional genomics. Am J Pathol 2003, 163(2):69|-700.

50. Shimoji T, Kanda $H$, Kitagawa T, Kadota K, Asai R, Takahashi $K$ Kawaguchi N, Matsumoto S, Hayashizaki Y, Okazaki Y, et al.: Clinicomolecular study of dedifferentiation in well-differentiated liposarcoma. Biochem Biophys Res Commun 2004, 3I4(4): I I33-I I 40.

5I. Kim Jl, Choi KU, Lee IS, Moon TY, Lee CH, Kim HW, Kim JY, Park DY, Sol MY: Gene expression in mixed type liposarcoma. Pathology 2006, 38(2): I I4-II9.

52. Bui NB, Coindre JM, Maree D, Trojani M: Liposarcoma: patterns of tumor differentiation following induction chemotherapy. Oncology 1984, 4 I(3): I70-173.

53. Gebhard S, Coindre JM, Michels IJ, Terrier P, Bertrand G, Trassard M, Taylor S, Chateau MC, Marques B, Picot V, et al.: Pleomorphic liposarcoma: clinicopathologic, immunohistochemical, and follow-up analysis of 63 cases: a study from the French Federation of Cancer Centers Sarcoma Group. Am J Surg Pathol 2002, 26(5):60I-6I6

54. Henricks WH, Chu YC, Goldblum JR, Weiss SW: Dedifferentiated liposarcoma: a clinicopathological analysis of 155 cases with a proposal for an expanded definition of dedifferentiation. Am J Surg Pathol 1997, 2 I (3):27I-28I.

55. McCormick D, Mentzel T, Beham A, Fletcher CD: Dedifferentiated liposarcoma. Clinicopathologic analysis of 32 cases suggesting a better prognostic subgroup among pleomorphic sarcomas. Am J Surg Pathol 1994, I 8( I 2): 12 13-1223.

56. Kindblom LG: Lipomatous tumors-how we have reached our present views, what controversies remain and why we still face diagnostic problems: a tribute to Dr Franz Enzinger. Adv Anat Pathol 2006, 13(6):279-285.

57. Sreekantaiah C, Karakousis CP, Leong SP, Sandberg AA: Cytogenetic findings in liposarcoma correlate with histopathologic subtypes. Cancer 1992, 69(10):2484-2495.

58. Lehnhardt M, Muehlberger T, Kuhnen C, Brett D, Steinau HU, Jafari $\mathrm{H}$, Steinstraesser L, Muller O, Homann HH: Feasibility of chemosensitivity testing in soft tissue sarcomas. World J Surg Oncol 2005, 3(I):20.

59. Joyner DE, Bastar JD, Randall RL: Doxorubicin induces cell senescence preferentially over apoptosis in the FU-SY-I synovial sarcoma cell line. J Orthop Res 2006, 24(6): I |63-1 I69.

60. Francis $\mathrm{P}$, Fernebro J, Eden P, Laurell A, Rydholm A, Domanski HA, Breslin T, Hegardt C, Borg A, Nilbert M: Intratumor versus intertumor heterogeneity in gene expression profiles of soft-tissue sarcomas. Genes Chromosomes Cancer 2005, 43(3):302-308. 
6I. Goss G, Demetri G: Medical management of unresectable, recurrent low-grade retroperitoneal liposarcoma: integration of cytotoxic and non-cytotoxic therapies into multimodality care. Surg Oncol 2000, 9(2):53-59.

62. Evdokiou A, Bouralexis S, Atkins GJ, Chai F, Hay S, Clayer M, Findlay DM: Chemotherapeutic agents sensitize osteogenic sarcoma cells, but not normal human bone cells, to Apo2L/TRAILinduced apoptosis. Int J Cancer 2002, 99(4):49I-504.

63. Komdeur R, Meijer C, Van Zweeden M, De Jong S, Wesseling J, Hoekstra HJ, Graaf WT van der: Doxorubicin potentiates TRAIL cytotoxicity and apoptosis and can overcome TRAIL-resistance in rhabdomyosarcoma cells. Int J Oncol 2004, 25(3):677-684.

64. Bouralexis S, Findlay DM, Atkins GJ, Labrinidis A, Hay S, Evdokiou A: Progressive resistance of BTK-I43 osteosarcoma cells to Apo2L/TRAIL-induced apoptosis is mediated by acquisition of DcR2/TRAIL-R4 expression: resensitisation with chemotherapy. $\mathrm{Br}$ / Cancer 2003, 89(I):206-2I4

65. Bouralexis S, Clayer M, Atkins GJ, Labrinidis A, Hay S, Graves S, Findlay DM, Evdokiou A: Sensitivity of fresh isolates of soft tissue sarcoma, osteosarcoma and giant cell tumour cells to Apo2L/TRAIL and doxorubicin. Int $J$ Oncol 2004 24(5): $1263-1270$.

66. Ganjavi H, Gee M, Narendran A, Freedman MH, Malkin D: Adenovirus-mediated p53 gene therapy in pediatric soft-tissue sarcoma cell lines: sensitization to cisplatin and doxorubicin. Cancer Gene Ther 2005, I 2(4):397-406.

67. Chang BD, Xuan Y, Broude EV, Zhu H, Schott B, Fang J, Roninson IB: Role of p53 and p2Iwafl/cipl in senescence-like terminal proliferation arrest induced in human tumor cells by chemotherapeutic drugs. Oncogene 1999 , I 8(34):4808-48| 8 .

68. Van Valen F, Fulda S, Schafer KL, Truckenbrod B, Hotfilder M, Poremba C, Debatin KM, Winkelmann W: Selective and nonselective toxicity of TRAIL/Apo2L combined with chemotherapy in human bone tumour cells vs. normal human cells. Int J Cancer 2003, I07(6):929-940.

69. Li W, Fan J, Bertino JR: Selective sensitization of retinoblastoma protein-deficient sarcoma cells to doxorubicin by flavopiridol-mediated inhibition of cyclin-dependent kinase 2 kinase activity. Cancer Res 200I, 6 I (6):2579-2582

70. Vigneron A, Roninson IB, Gamelin E, Coqueret O: Src inhibits adriamycin-induced senescence and $G 2$ checkpoint arrest by blocking the induction of p2Iwafl. Cancer Res 2005 , 65(19):8927-8935.

71. Papa S, Zazzeroni F, Bubici C, Jayawardena S, Alvarez K, Matsuda S, Nguyen DU, Pham CG, Nelsbach AH, Melis T, et al.: Gadd45 beta mediates the NF-kappa B suppression of JNK signalling by targeting MKK7/JNKK2. Nat Cell Biol 2004, 6(2):| 46-| 53.

72. Lauricella M, Emanuele S, D'Anneo A, Calvaruso G, Vassallo B, Carlisi D, Portanova P, Vento R, Tesoriere G: JNK and AP-I mediate apoptosis induced by bortezomib in HepG2 cells via FasL/ caspase-8 and mitochondria-dependent pathways. Apoptosis 2006, I I (4):607-625.

73. Jin Z, El-Deiry WS: Distinct signaling pathways in TRAIL-versus tumor necrosis factor-induced apoptosis. Mol Cell Biol 2006 , 26(2I):8I36-8|48.

74. Mikami T, Koyama T, Koyama T, Imakiire A, Yamamoto K, Furuhata $\mathrm{M}$, Toyota $\mathrm{H}$, Mizuguchi ]: $\mathbf{C}$-jun $\mathbf{N}$-terminal kinase activation is required for apoptotic cell death induced by TNF-related apoptosis-inducing ligand plus DNA-damaging agents in sarcoma cell lines. Anticancer Res 2006, 26: I I 53- I I60.

75. Kappler R, Bauer R, Calzada-Wack J, Rosemann M, Hemmerlein B, $\mathrm{Hahn} \mathrm{H}$ : Profiling the molecular difference between Patchedand p53-dependent rhabdomyosarcoma. Oncogene 2004, 23(54):8785-8795.

76. Mitsiades N, Yu WH, Poulaki V, Tsokos M, Stamenkovic I: Matrix metalloproteinase-7-mediated cleavage of Fas ligand protects tumor cells from chemotherapeutic drug cytotoxicity. Cancer Res 2001, 6 I (2):577-58I.

77. Poulaki V, Mitsiades CS, Mitsiades N: The role of Fas and FasL as mediators of anticancer chemotherapy. Drug Resist Updat 200I, 4(4):233-242.

78. Li W, Bertino JR: Fas-mediated signaling enhances sensitivity of human soft tissue sarcoma cells to anticancer drugs by activation of p38 kinase. Mol Cancer Ther 2002, I ( I 4): | 343- I 348 .
79. Ottaiano A, De Chiara A, Perrone F, Botti G, Fazioli F, De Rosa V Mozzillo N, Ravo V, Morrica B, Gallo C, et al.: Prognostic value of CD40 in adult soft tissue sarcomas. Clin Cancer Res 2004, I0(8):2824-2831.

80. Lodge A, Yu P, Nicholl MB, Brown IE, Jackson CC, Schreiber K, Sugg $\mathrm{SL}$, Schreiber $\mathrm{H}$, Shilyansky J: CD40 ligation restores cytolytic T lymphocyte response and eliminates fibrosarcoma in the peritoneum of mice lacking CD4+ $\mathbf{T}$ cells. Cancer Immunol Immunother 2006, 55( ( 2): I542-I552.

8I. Power CP, Wang JH, Manning B, Kell MR, Aherne NF, Wu QD, Redmond HP: Bacterial lipoprotein delays apoptosis in human neutrophils through inhibition of caspase-3 activity: regulatory roles for CDI4 and TLR-2. J Immunol 2004, I 73(8):5229-5237.

82. Gregory CD, Devitt A: CDI4 and apoptosis. Apoptosis 1999 4(I): I I-20

83. Mills KI, Woodgate LJ, Gilkes AF, Walsh V, Sweeney MC, Brown G, Burnett AK: Inhibition of mitochondrial function in HL60 cells is associated with an increased apoptosis and expression of CDI4. Biochem Biophys Res Commun 1999, 263(2):294-300.

84. Mocellin S, Provenzano M, Lise M, Nitti D, Rossi CR: Increased TIA-I gene expression in the tumor microenvironment after locoregional administration of tumor necrosis factor-alpha to patients with soft tissue limb sarcoma. Int J Cancer 2003, I07(2):317-322.

85. Berg $D$, Holzmann $C$, Riess $O$ : 1 4-3-3 proteins in the nervous system. Nat Rev Neurosci 2003, 4(9):752-762.

86. Ostrerova N, Petrucelli L, Farrer M, Mehta N, Choi P, Hardy J, Wolozin B: alpha-Synuclein shares physical and functional homology with I4-3-3 proteins. J Neurosci 1999 , I 9( I 4):5782-579|.

87. Jin Y, Dai MS, Lu SZ, Xu Y, Luo Z, Zhao Y, Lu H: I4-3-3gamma binds to MDMX that is phosphorylated by UV-activated Chkl, resulting in p53 activation. Embo J 2006, 25(6): $|207-12| 8$.

88. Namkoong H, Shin SM, Kim HK, Ha SA, Cho GW, Hur SY, Kim TE, Kim JW: The bone morphogenetic protein antagonist gremlin $I$ is overexpressed in human cancers and interacts with YWHAH protein. BMC Cancer 2006, 6:74.

89. Chen $Y$, Du $X Y$ : Functional properties and intracellular signaling of CCN I/Cyr6 I. J Cell Biochem 2007, I 00(6): I 337-I 345.

90. Rees H, Williamson D, Papanastasiou A, Jina N, Nabarro S, Shipley J, Anderson J: The MET receptor tyrosine kinase contributes to invasive tumour growth in rhabdomyosarcomas. Growth Factors 2006, 24(3): 197-208.

91. Mayadas TN, Cullere X: Neutrophil beta2 integrins: moderators of life or death decisions. Trends Immunol 2005 , 26(7):388-395

92. Hood JD, Cheresh DA: Role of integrins in cell invasion and migration. Nat Rev Cancer 2002, 2(2):91-100.

93. Sotobori T, Ueda T, Oji Y, Naka N, Araki N, Myoui A, Sugiyama $H$, Yoshikawa H: Prognostic significance of Wilms tumor gene (WTI) mRNA expression in soft tissue sarcoma. Cancer 2006. I 06( I 0):2233-2240.

94. Coosemans A, Nik SA, Caluwaerts S, Lambin S, Verbist G, Van Bree $\mathrm{R}$, Schelfhout $\mathrm{V}$, de Jonge $\mathrm{E}$, Dalle I, Jacomen $\mathrm{G}$, et al.: Upregulation of Wilms' tumour gene I (WTI) in uterine sarcomas. Eur J Cancer 2007, 43(10): 1630-1637.

95. Martinez N, Sanchez-Beato M, Carnero A, Moneo V, Tercero JC, Fernandez I, Navarrete M, Jimeno J, Piris MA: Transcriptional signature of Ecteinascidin 743 (Yondelis, Trabectedin) in human sarcoma cells explanted from chemo-naive patients. Mol Cancer Ther 2005, 4(5):8I4-823.

96. Garcia-Cao I, Duran A, Collado M, Carrascosa MJ, Martin-Caballero J, Flores JM, Diaz-Meco MT, Moscat J, Serrano M: Tumour-suppression activity of the proapoptotic regulator Par4. EMBO Rep 2005, 6(6):577-583.

97. Wissing $D$, Mouritzen $\mathrm{H}$, Jaattela M: TNF-induced mitochondrial changes and activation of apoptotic proteases are inhibited by A20. Free Radic Biol Med I998, 25(I):57-65.

98. Saitoh T, Yamamoto M, Miyagishi M, Taira K, Nakanishi M, Fujita T, Akira S, Yamamoto $\mathrm{N}$, Yamaoka $S$ : A20 is a negative regulator of IFN regulatory factor $\mathbf{3}$ signaling. I Immunol 2005 , I 74(3): $|507-15| 2$. 
99. Campbell KJ, O'Shea JM, Perkins ND: Differential regulation of NF-kappaB activation and function by topoisomerase II inhibitors. BMC Cancer 2006, 6:101.

100. Park HJ, Chung HJ, Min HY, Park EJ, Hong JY, Kim WB, Kim SH, Lee SK: Inhibitory effect of DA-125, a new anthracyclin analog antitumor agent, on the invasion of human fibrosarcoma cells by down-regulating the matrix metalloproteinases. Biochem Pharmacol 2005, 7I: I-2.

101. Hu Q, Zhou MX, Liu SY, Zhang LQ, Liu AQ, Guo Y], Song Y: [Regulation of NF-kappaB/P65 by MDM2 in acute lymphoblastic leukemia in childhood]. Zhonghua $\mathrm{Er} \mathrm{Ke} \mathrm{Za} \mathrm{Zhi} \mathrm{2003,}$ 4I( I 2): $921-924$

102. Grobe O, Arlt A, Ungefroren H, Krupp G, Folsch UR, Schmidt WE, Schafer H: Functional disruption of IEX-I expression by concatemeric hammerhead ribozymes alters growth properties of 293 cells. FEBS Lett 200I, 494(3): 196-200.

103. Schafer H, Trauzold A, Sebens T, Deppert W, Folsch UR, Schmidt WE: The proliferation-associated early response gene p22/ PRGI is a novel p53 target gene. Oncogene 1998, I 6(19):2479-2487.

104. Wang HQ, Nakaya Y, Du Z, Yamane T, Shirane M, Kudo T, Takeda M, Takebayashi K, Noda Y, Nakayama KI, et al.: Interaction of presenilins with FKBP38 promotes apoptosis by reducing mitochondrial Bcl-2. Hum Mol Genet 2005, I 4(I3): I 889-1902.

105. McCarthy JV, Ni J, Dixit VM: RIP2 is a novel NF-kappaB-activating and cell death-inducing kinase. J Biol Chem 1998, 273(27): 16968-16975.

106. Sarkar A, Duncan M, Hart J, Hertlein E, Guttridge DC, Wewers MD: ASC directs NF-kappaB activation by regulating receptor interacting protein-2 (RIP2) caspase-I interactions. J Immunol 2006, I 76(8):4979-4986.

107. Formisano P, Perruolo G, Libertini S, Santopietro S, Troncone G, Raciti GA, Oriente F, Portella G, Miele C, Beguinot F: Raised expression of the antiapoptotic protein ped/pea-15 increases susceptibility to chemically induced skin tumor development. Oncogene 2005, 24(47):70I2-702I.

108. Nagy B, Lundan T, Larramendy ML, Aalto Y, Zhu Y, Niini T, Edgren $\mathrm{H}$, Ferrer A, Vilpo J, Elonen E, et al.: Abnormal expression of apoptosis-related genes in haematological malignancies: overexpression of MYC is poor prognostic sign in mantle cell lymphoma. Br J Haematol 2003, $120(3): 434-44 I$.

109. Ushizawa K, Takahashi T, Kaneyama K, Hosoe M, Hashizume K: Cloning of the bovine antiapoptotic regulator, BCL2-related protein $\mathrm{Al}$, and its expression in trophoblastic binucleate cells of bovine placenta. Biol Reprod 2006, 74(2):344-35I.

1 10. Astolfi A, Nanni P, Landuzzi L, Ricci C, Nicoletti G, Rossi I, Lollini PL, De Giovanni C: An anti-apoptotic role for NGF receptors in human rhabdomyosarcoma. Eur J Cancer 200I, 37(13): 1719-1725.

III. Kilic M, Kasperczyk H, Fulda S, Debatin KM: Role of hypoxia inducible factor-I alpha in modulation of apoptosis resistance. Oncogene 2007, 26(I 4):2027-2038.

1 12. Nomura T, Yamasaki M, Nomura Y, Mimata H: Expression of the inhibitors of apoptosis proteins in cisplatin-resistant prostate cancer cells. Oncol Rep 2005, 14(4):993-997.

113. Hauptschein RS, Sloan KE, Torella C, Moezzifard R, Giel-Moloney M, Zehetmeier C, Unger C, llag LL, Jay DG: Functional proteomic screen identifies a modulating role for CD44 in death receptor-mediated apoptosis. Cancer Res 2005, 65(5): | 887-1896.

I 14. Misra S, Ghatak S, Toole BP: Regulation of MDR I expression and drug resistance by a positive feedback loop involving hyaluronan, phosphoinositide 3-kinase, and ErbB2. J Biol Chem 2005, 280(2I):20310-203I5.

1 I5. Eliaz RE, Nir S, Marty C, Szoka FC Jr: Determination and modeling of kinetics of cancer cell killing by doxorubicin and doxorubicin encapsulated in targeted liposomes. Cancer Res 2004, 64(2):7|I-7|8.

\section{Pre-publication history}

The pre-publication history for this paper can be accessed here:

http://www.biomedcentral.com/1471-2407/8/313/pre pub
Publish with BioMed Central and every scientist can read your work free of charge

"BioMed Central will be the most significant development for disseminating the results of biomedical research in our lifetime. "

Sir Paul Nurse, Cancer Research UK

Your research papers will be:

- available free of charge to the entire biomedical community

- peer reviewed and published immediately upon acceptance

- cited in PubMed and archived on PubMed Central

- yours - you keep the copyright

Submit your manuscript here:

http://www.biomedcentral.com/info/publishing_adv.asp
BioMedcentral 